\title{
Seasonal and event-scale variation in growth of Calanus agulhensis (Copepoda) in the Benguela upwelling system and implications for spawning of sardine Sardinops sagax
}

\author{
Anthony J. Richardson ${ }^{1,3, *}$, Hans M. Verheye ${ }^{2}$, Betty A. Mitchell-Innes ${ }^{2}$, \\ Justine L. Fowler ${ }^{2}$, John G. Field ${ }^{1}$ \\ ${ }^{1}$ Marine Biology Research Institute, Zoology Dept., University of Cape Town, Rondebosch 7701, South Africa \\ ${ }^{2}$ Marine and Coastal Management, Private Bag X2, Rogge Bay 8012, South Africa \\ ${ }^{3}$ Present address: The Sir Alister Hardy Foundation for Ocean Science (SAHFOS), The Laboratory, Citadel Hill, \\ Plymouth PL1 2PB, United Kingdom
}

\begin{abstract}
We investigated the growth rate and egg production of Calanus agulhensis, the dominant copepod on the western Agulhas Bank region of the southern Benguela upwelling system (South Africa), and assessed the implications for the spawning of sardine Sardinops sagax. Daily weight specific growth rate (SGR) of copepod developmental stages (N6 to female) was measured monthly between September and March 1993/94 and 1994/95. Seasonally, SGRs of small stages (N6 to $\mathrm{C} 2$ ) remained relatively constant. By contrast, SGRs of large stages (C3 to female) mirrored changes in chl a related to seasonal warming and wind patterns, with a moderate peak in September/October and a larger peak in January to March. Superimposed on this seasonal cycle were fluctuations in response to winds on the event scale. At the onset of upwelling, mean female SGR across the shelf was slow. During sustained upwelling, female SGR increased, with a peak associated with enhanced chl $a$ in the upwelling front and slower rates inshore in newly upwelled water and offshore in oligotrophic water. Female SGR was fastest during prolonged quiescence when high chl a levels extended over most of the shelf. During downwelling, female SGRs decreased again, with fastest rates inshore. Overall, SGRs were not related to temperature, but were related to chl $a$, with stronger relationships for larger stages. This suggested food limitation of larger stages, which may be a consequence of their preference for larger phytoplankton cells that only occur at high concentrations in restricted locations in time and space in the southern Benguela upwelling system. The spawning of sardine varied seasonally and coincided with the maximum chl a concentration and production of C. agulhensis eggs (daily egg production $\times$ female density), both of which are a good source of food for fish larvae. Thus the timing of sardine spawning maximizes the food available to their larvae.
\end{abstract}

KEY WORDS: Copepods · Specific growth rate · Calanus · Egg production - Somatic growth · Sardine $\cdot$ Spawning $\cdot$ Larval food

Resale or republication not permitted without written consent of the publisher

\section{INTRODUCTION}

Copepod production is an important factor influencing fish recruitment (Cushing 1990, Pederson et al. 1990). Copepod eggs and nauplii are food items for larval fish (Turner 1984), especially first-feeding larvae which are particularly vulnerable to starvation (Blaxter
\& Hunter 1982). The spawning of many fish coincides with the maximum food availability in terms of copepod production for their larvae (Cushing 1990). Thus, copepod production may be of crucial importance to understanding the recruitment variability of fish.

Davis (1987) argued that the only way to measure zooplankton production accurately is by estimation of 
species-specific growth rates. Research on copepod production in the field has focused on female egg production (Durbin et al. 1992, Plourde \& Runge 1993, Jónasdóttir et al. 1995, McKinnon \& Ayukai 1996, Pond et al. 1996) rather than juvenile growth, because of its ease of measurement by direct bottle incubation. Most research on juvenile growth has been conducted in temperate and polar regions, where the progression of cohorts after spring or fall phytoplankton blooms has been followed (McLaren \& Corkett 1981, Middlebrook \& Roff 1986, McLaren et al. 1989). Few studies have measured juvenile growth rate and female egg production simultaneously in dynamic regions such as upwelling areas (however see Walker \& Peterson 1991), where the use of distinct cohorts to estimate juvenile growth is difficult because female egg production is quasi-continuous.

In this study, juvenile growth rates of Calanus agulhensis (nauplius N6 to copepodite C5) were estimated by the moulting ratio method, and female egg production by the egg production method (see Peterson et al. 1991). The study area was the western Agulhas Bank region of the southern Benguela upwelling system. In this region, $C$. agulhensis is the dominant copepod (Huggett \& Richardson 2000), constituting up to $85 \%$ of the biomass of copepods (Verheye et al. 1994). Importantly, the western Agulhas Bank is a major spawning area for pelagic fish such as sardine (Shelton 1986, Huggett et al. 1998).

The hydrography of this region is highly dynamic (Largier et al. 1992). During winter, northerly and westerly winds dominate (Shannon 1985), mixing the water column to below $100 \mathrm{~m}$ (Boyd et al. 1985). Thereafter, south-easterly winds increase, favouring upwelling (Jury 1988). Hydrographic conditions are most variable during late summer (Boyd et al. 1985, Largier et al. 1992, Richardson et al. 1998, Mitchell-Innes et al. 1999), particularly January to March when event-scale variation in response to periodic wind events is greatest (Jury 1988). Based on cruises conducted during the dynamic January to March period, 4 phases of upwelling have been identified (Mitchell-Innes et al. 1999). The first phase is the onset of upwelling, when cold $\left(<12^{\circ} \mathrm{C}\right)$ water upwells inshore and a surface front emerges in response to southeasterly winds. The second phase, sustained upwelling, occurs after prolonged south-easterly winds and is characterized by the offshore movement of the upwelling and oceanic fronts, and warming and stabilization of the upwelled water. The third phase, quiescence, follows weak and variable winds and is distinguished by the absence of an upwelling front, further warming and stratification of the water column, and the oceanic front located at the shelf-edge. The last phase, downwelling, follows north-westerly winds that cause onshore flow and relaxation of the oceanic front shoreward.
The aims of this study were 2 -fold. First, we wished to understand the variations in growth and egg production of Calanus agulhensis (N6 to female) on the western Agulhas Bank in terms of physical and biological forcing in this dynamic upwelling region. On a broad scale, $C$. agulhensis growth rates and egg production are interpreted in terms of seasonal hydrographic variability. At the event scale, characteristic cross-shelf patterns were identified for the 4 phases of upwelling defined by Mitchell-Innes et al. (1999). These patterns in growth and egg production were then related to temperature and chl a concentration. Our second aim was to relate the spawning of sardine to 2 measures of a suitable food environment for sardine larvae. These measures were chl a concentration and the production of $C$. agulhensis eggs, estimated as the product of female density and daily egg production.

\section{MATERIALS AND METHODS}

Sampling was conducted monthly between August 1993 and March 1994, and between September 1994 and March 1995 (except January 1995), aboard the South African Marine and Coastal Management RVs 'Algoa' and 'Africana', and the Norwegian RV 'Dr Fridtjof Nansen'. Two transects, each comprising 6 stations 10 nautical miles apart, were sampled on the western Agulhas Bank (Fig. 1), South Africa, as part of the South African Sardine and Anchovy Recruitment Programme (SARP) (Painting 1993).

Hourly wind speed and direction during the study period were obtained from the Cape Point lighthouse.

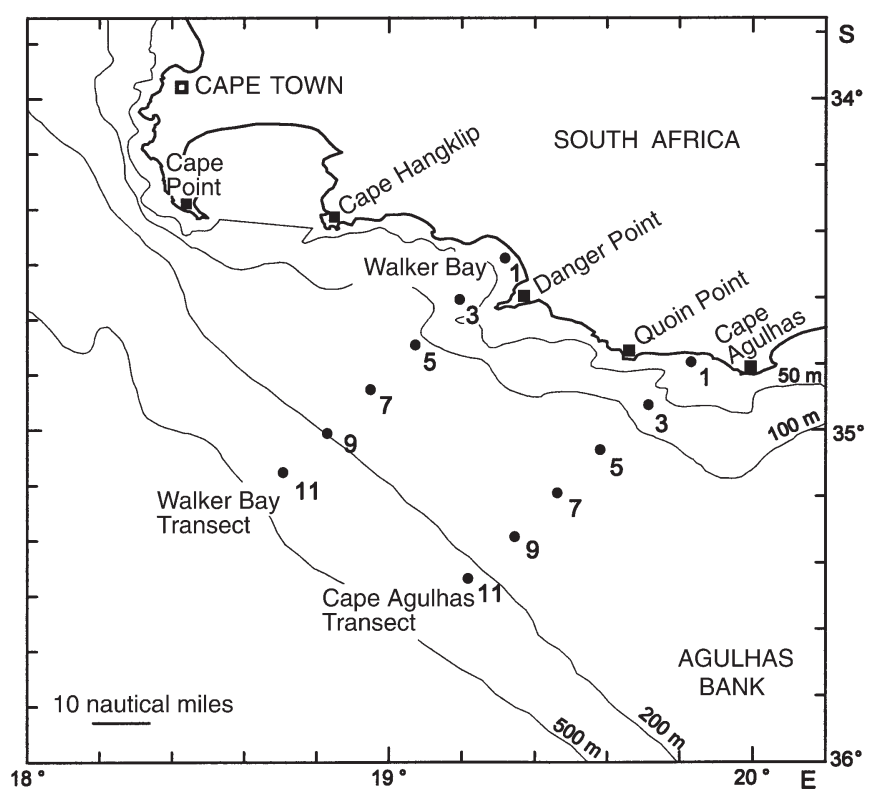

Fig. 1. Survey grid of the SARP programme on the western Agulhas Bank 
Winds at Cape Point are representative of winds on the western Agulhas Bank east to Walker Bay (L. Hutchings pers. comm.). Thus, only the hydrography on the Walker Bay Transect is directly related to winds in this study, and not of the Cape Agulhas Transect further east. Moreover, only winds prior to $2 \mathrm{~d}$ before the time that each transect was sampled are shown, because there is a 2 d delay between winds and the hydrographic response on the western Agulhas Bank (Jury 1988).

Although members of the genus Calanus are considered to be largely herbivorous (Turner 1984, Mauchline 1998 and references therein), there has been increasing recognition of the role of omnivory in the diet of calanoid copepods (Gifford 1993, Kleppel 1993, Harris 1996). Unfortunately there is no information on the extent of omnivory in C. agulhensis (Huggett \& Richardson 2000). However, there is some evidence, albeit indirect, concerning the dietary preference of $C$. agulhensis: protozoans constitute a relatively small proportion of the diet in the sibling species $C$. finmarchicus (Gifford 1993), and picoplankton may be too small to be consumed efficiently (Peterson \& Bellantoni 1987, Walker \& Peterson 1991). Thus we have used the concentration of chl $a$ as a measure of ambient food availability for C. agulhensis.

At each station, $250 \mathrm{ml}$ of seawater was filtered through GF/F filters, extracted in $90 \%$ acetone for $24 \mathrm{~h}$ at $-20^{\circ} \mathrm{C}$, and analyzed fluorometrically using a Turner Designs Model 10-000R fluorometer. The concentration of chl a was adjusted for phaeopigments by reading fluorescence before and after acidification with $10 \% \mathrm{HCl}$ (Parsons et al. 1984). Fluorescence and temperature profiles were determined using a Chelsea Instruments Aquatracka and thermistor. Surface nitrate samples were also collected, and analyzed according to the methods of Mostert (1988).

At each station, egg production of female Calanus agulhensis and growth rates of its juveniles were estimated using bottle incubation techniques (Hutchings et al. 1995). Copepods were collected using a $300 \mu \mathrm{m}$ mesh drift-net fitted with a 21 plastic bottle as a codend. This net was lowered for $10 \mathrm{~min}$ to the depth of maximum fluorescence determined previously from a fluorescence profile. Upon retrieval, the sample was diluted in a bucket containing 201 of seawater at ambient surface temperature. Copepods were concentrated from this bucket using a sieve and washed into a petri dish. Specimens were selected using a wide-mouthed dropper under a dissecting microscope. Females were placed individually in 11 bottles to estimate egg production. Usually between 5 and 10 replicate experiments were performed at each station. Although the bottles were not fitted with a screen to prevent females from ingesting their eggs, the low density of females $\left(1\right.$ female $^{-1}$ ) and the constant movement of the bottles during incubation minimized the effects of possible egg cannibalism (Laabir et al. 1995). In addition, many females produced high numbers of eggs (up to 131 eggs in a $24 \mathrm{~h}$ period), so that cannibalism was not considered to be a major problem. To estimate the moulting rate of juveniles, at least 15 individuals (mean $=36)$ of a stage were incubated in 21 jars. All copepods were incubated in $63 \mu \mathrm{m}$ filtered seawater collected at the depth of maximum fluorescence. The entire pre-incubation procedure usually lasted $<30 \mathrm{~min}$. Bottles were incubated in on deck darkened tubs, which were kept at ambient temperature by pumping seawater from a depth of $6 \mathrm{~m}$ (as described by Hutchings et al. 1995). After $24 \mathrm{~h}$ the contents of the bottles were poured through a $63 \mu \mathrm{m}$ mesh and the retained sample preserved with $5 \%$ buffered formalin. This sample was later counted in the laboratory.

To aid comparison between rates of female egg production and juvenile growth rates, female daily weightspecific growth rate $\left(\mathrm{SGR}_{\mathrm{f}}, \mu \mathrm{gDW} \mu \mathrm{gDW} \mathrm{W}^{-1} \mathrm{~d}^{-1}\right.$, where $\mathrm{DW}=$ dry weight) will be used to denote the 'growth' equivalent to egg production, and was calculated (Peterson et al. 1991) by:

$$
\mathrm{SGR}_{\mathrm{f}}=\frac{N_{\mathrm{e}} \times W_{\mathrm{e}}}{W_{\mathrm{f}}} \times \frac{24}{T}
$$

where $N_{\mathrm{e}}=$ the number of eggs per bottle, $W_{\mathrm{e}}=$ average egg weight $(\mu \mathrm{gDW}), W_{\mathrm{f}}=$ average weight of female ( $\mu \mathrm{gDW})$, and $T=$ the duration of the incubation experiment (h). This definition of SGR is synonomous with previous work on copepod growth rates that have used units of $\mathrm{d}^{-1}$. Owing to the large number of females incubated ( $\mathrm{n}=876$ ), an assumption of average body mass of females (202 $\mu \mathrm{g}$ DW) and eggs (0.6 $\mu \mathrm{g}$ DW) has been used.

For moulting ratio experiments, the number of individuals that had or had not moulted to the next stage were counted and the juvenile daily weight-specific growth rate $\left(\mathrm{SGR}_{\mathrm{i}}, \mu \mathrm{gDW} \mu \mathrm{gDW} \mathrm{DW}^{-1} \mathrm{~d}^{-1}\right)$ calculated from the moulting ratio (modified from Peterson et al. 1991):

$$
\mathrm{SGR}_{\mathrm{i}}=\ln \left(\frac{W_{\mathrm{i}+1}}{W_{\mathrm{i}}}\right) \times \frac{N_{\mathrm{i}+1}}{N_{\mathrm{i}}+N_{\mathrm{i}+1}} \times \frac{24}{T}
$$

where $W_{i}=$ average weight of an individual in stage $i$, $W_{\mathrm{i}+1}=$ average weight of an individual in stage $\mathrm{i}+1$, $N_{\mathrm{i}}=$ the number of individuals in stage $\mathrm{i}$ at the end of the experiment and $N_{i+1}=$ the number of individuals in stage $i+1$ at the end of the experiment.

Exoskeletons were also counted and experiments were excluded from the analysis if the difference between the moulting ratio calculated from the exoskeletons and that from the animals themselves was greater than $10 \%$. The assumption of mean masses for Calanus agulhensis stages N6 (2 $\mu \mathrm{gDW}), \mathrm{C} 1(4 \mu \mathrm{gDW})$, C2 $(9 \mu \mathrm{gDW}), \mathrm{C} 3(22 \mu \mathrm{gDW}), \mathrm{C} 4(46 \mu \mathrm{gDW})$ and C5 (97 $\mu \mathrm{g} \mathrm{DW})$ was made because of the large number of 
individuals incubated $(\mathrm{n}=10260)$, and the suggestion that growth rates are more sensitive to changes in moulting ratios than growth increments (Webber \& Roff 1995). The issue of whether the number of individuals in an incubation bottle affects the measured SGR through food limitation is assessed in the 'Results'.

Data on sea surface temperature, surface nitrate, chl $a$ and SGR were combined for the 2 transects sampled and contoured by the method of kriging using SURFER $^{\circledR}$ for Windows (Golden Software). Only female SGR was contoured because there were insufficient data for juvenile stages (Table 1). Hydrographic conditions between January and March on the Cape Agulhas and Walker Bay Transects were categorized into the 4 upwelling phases defined by Mitchell-Innes et al. (1999). This enabled characteristic cross-shelf patterns of female SGR to be determined for each phase of the upwelling cycle.

Not all stages were equally available during each cruise, so the number of experiments performed varied considerably (Table 1). As the data collected for each stage were spatially and temporally unbalanced, SGRs were averaged so as to obtain unbiased station and monthly means. First, every station was given equal weighting by averaging all replicate SGR estimates made at that station and at that particular time. Then, the cross-shelf distribution of SGR for each month was averaged across all months, giving equal weighting to all monthly cross-shelf distributions. Similarly, to calculate an unbiased seasonal distribution of SGR, the seasonal distribution for each station was averaged across all stations, giving equal weighting to all seasonal distributions at each station.

Table 1. Calanus agulhensis. Number of growth rate and egg production experiments for N6 to female stages during each cruise

\begin{tabular}{|lrrrrrrr|}
\hline \multirow{2}{*}{ Cruise } & \multicolumn{7}{c|}{ No. of experiments } \\
& N6 & C1 & C2 & C3 & C4 & C5 & Female \\
\hline August 1993 & 0 & 0 & 0 & 0 & 0 & 0 & 18 \\
September 1993 & 0 & 1 & 1 & 2 & 0 & 1 & 53 \\
October 1993 & 1 & 2 & 2 & 3 & 5 & 4 & 80 \\
November 1993 & 1 & 9 & 15 & 13 & 8 & 8 & 39 \\
December 1993 & 0 & 2 & 4 & 3 & 4 & 3 & 34 \\
January 1994 & 0 & 0 & 0 & 0 & 1 & 4 & 92 \\
February 1994 & 0 & 0 & 0 & 2 & 3 & 3 & 121 \\
March 1994 & 0 & 2 & 2 & 2 & 5 & 3 & 76 \\
September 1994 & 0 & 2 & 0 & 3 & 6 & 6 & 38 \\
October 1994 & 1 & 0 & 5 & 5 & 3 & 4 & 53 \\
November 1994 & 7 & 15 & 14 & 14 & 12 & 12 & 97 \\
December 1994 & 2 & 2 & 1 & 2 & 3 & 4 & 43 \\
February 1995 & 1 & 3 & 4 & 5 & 4 & 4 & 71 \\
March 1995 & 0 & 3 & 3 & 4 & 6 & 6 & 61 \\
Total & 13 & 41 & 51 & 58 & 60 & 62 & 876 \\
& & & & & & & \\
\hline
\end{tabular}

The relationship between the spawning of sardine and the food available to their larvae was assessed by regressing sardine spawning intensity against an estimate of the amount of suitably-sized food for larvae. The index of sardine spawning intensity used was the total number of eggs on the western Agulhas Bank each month. This was calculated by taking the geometric mean of the egg density at each station and the total proportion of the sampling area in which eggs were found. The sardine egg density at each station was obtained from a CALVET net tow to $70 \mathrm{~m}$. March 1994 and March 1995 were not included in the analysis because sardine have generally finished spawning at this time (Shelton 1986, Huggett et al. 1998). Two measures of food availability to sardine larvae were used. These were the surface chl a concentration and the number of Calanus agulhensis eggs produced. Phytoplankton containing chl $a$ and copepod eggs are a suitably-sized food source for clupeoid larvae (Turner 1984), especially first-feeding larvae which are the most vulnerable to starvation (Blaxter \& Hunter 1982), although no doubt other food sources are also utilized. The number of eggs produced on the western Agulhas Bank at the time of each survey was estimated as the product of daily egg production (eggs female ${ }^{-1}$ $\mathrm{d}^{-1}$ ) and female density (no. $\mathrm{m}^{-3}$ ). Female density was determined from samples collected using a bongo net fitted with a $200 \mu \mathrm{m}$ mesh towed from $200 \mathrm{~m}$ depth (or from $5 \mathrm{~m}$ off the bottom, where shallower) to the surface. Samples were collected at the same stations as those for SGR.

\section{RESULTS}

\section{Seasonal and cross-shelf variation}

In August/September of 1993/94 and 1994/95, surface water was isothermal $\left(15^{\circ} \mathrm{C}\right.$, Fig. 2a,e). Water temperature warmed between October and December $\left(16\right.$ to $\left.19^{\circ} \mathrm{C}\right)$, but was still relatively isothermal across the shelf. Thereafter, cross-shelf temperatures were more variable. Cold $\left(<13^{\circ} \mathrm{C}\right)$ water prevailed on the inner shelf during upwelling in January 1994, February 1994 and March 1995, with relatively warmer water $\left(15\right.$ to $\left.18^{\circ} \mathrm{C}\right)$ inshore in March 1994 and February 1995. Offshore there was very warm water $\left(>21^{\circ} \mathrm{C}\right)$.

Nitrate concentrations were negatively related to water temperature (Fig. 2b,f). Elevated chl a concentrations generally corresponded to nitrate-rich water inshore (Fig. 2c,g) and very low concentrations coincided with warm $\left(18^{\circ} \mathrm{C}\right)$ oligotrophic water offshore. Seasonally, the chl a concentration was moderate ( 2 to $\left.6 \mathrm{mg} \mathrm{m}^{-3}\right)$ in September/October, low $\left(<2 \mathrm{mg} \mathrm{m}^{-3}\right)$ over most of the shelf in November/December and high 
$1993 / 94$
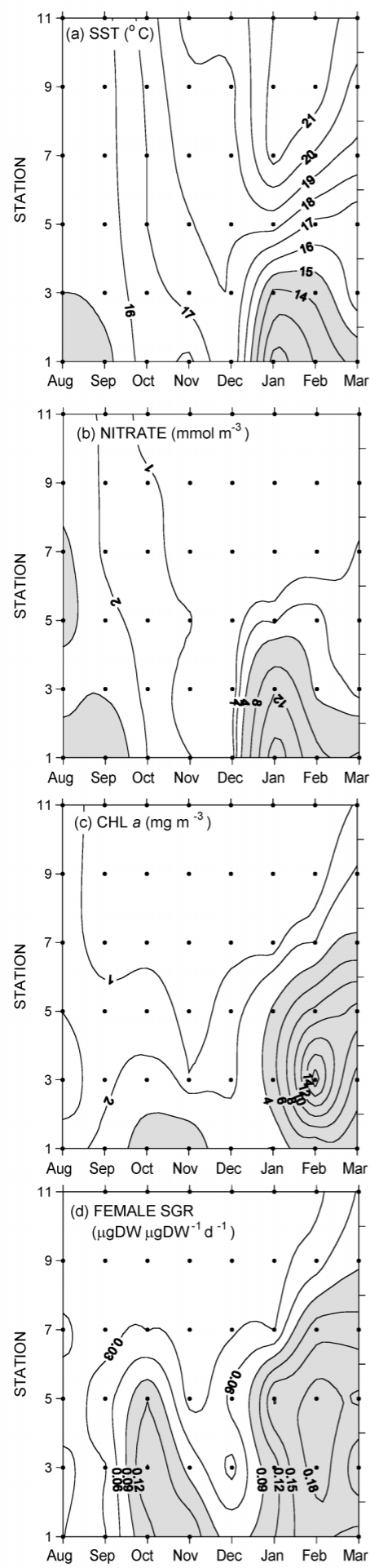

$1994 / 95$
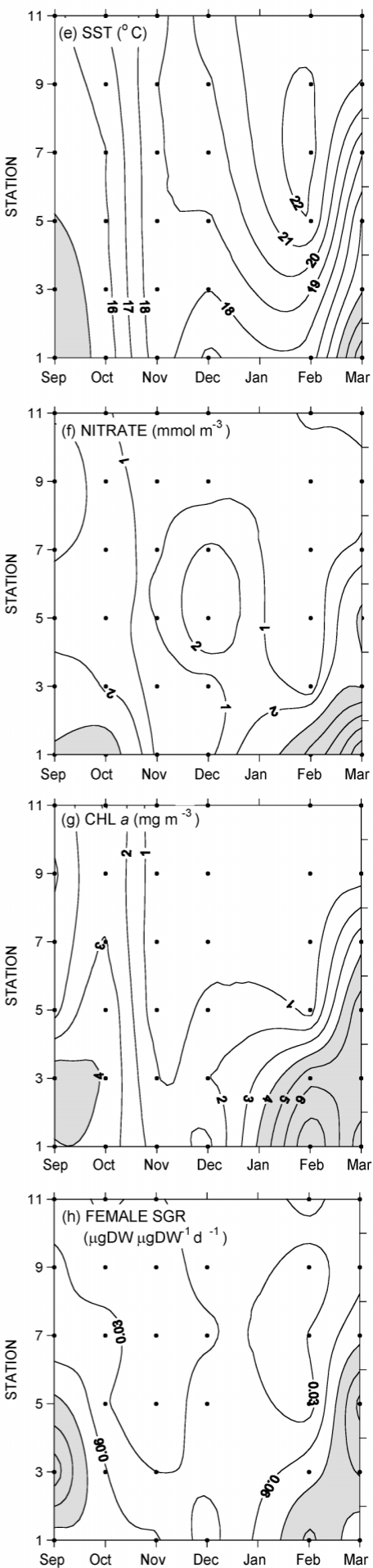

Fig. 2. Calanus agulhensis. Monthly and cross-shelf variation of (a and e) sea surface temperature (SST, $<15^{\circ} \mathrm{C}$ shaded), (b and f) surface nitrate ( $>4 \mathrm{mmol} \mathrm{m}^{-3}$ shaded), (c and $\mathrm{g}$ ) surface chl $a$ ( $>4 \mathrm{mg} \mathrm{m}^{-3}$ shaded), and ( $\mathrm{d}$ and $\mathrm{h}$ ) specific growth rate (SGR) of females (>0.09 $\mu \mathrm{gDW} \mu \mathrm{gDW}^{-1} \mathrm{~d}^{-1}$ shaded), between August 1993 and March 1994 (left) and between September 1994 and March 1995 (right). Stations are numbered from inshore to offshore (see Fig. 1). Data from both transects were combined. Dots represent stations where data were collected

( $>6 \mathrm{mg} \mathrm{m}^{-3}$ ) over a broad area between January and March, especially in 1993/94 (Fig. 2c,g). During strong upwelling, such as in January and February 1994, chl a concentration peaked midshelf, offshore of the cold nitrate-rich, newly-upwelled water (Fig. 2c,g).

SGRs of female Calanus agulhensis tracked the distri-

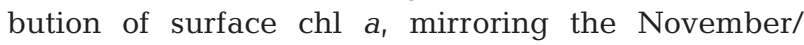
December and cross-shelf declines (Fig. 2d,h). Differences in the distribution of female SGR between the 2 sampling periods, such as an earlier initial peak in 1994/95, faster SGR in 1993/94, and a broader area of fast SGR from January to March 1994, reflected changes in the pattern of chl $a$ in each sampling period. It is noteworthy that SGRs were slow in warm $\left(>18^{\circ} \mathrm{C}\right)$ water.

SGRs of smaller stages (N6 to $\mathrm{C} 2$ ) were generally consistent across the shelf (1993/94 and 1994/95 data averaged, Fig. 3). By contrast, there was a strong cross-shelf decline in SGRs of larger copepodites (C3 to female, Fig. 3). The average cross-shelf distributions of chl $a$ and temperature are also shown, with temperature increasing offshore and chl a decreasing offshore. Thus, SGRs of large stages across the shelf are more similar to that of $\mathrm{chl} a$ than sea surface temperature. It is also notable that small stages grow faster than larger ones.

Seasonally, there was no clearly discernible pattern in the SGR of smaller stages (N6 to C2) for the sampling period (Fig. 4). By contrast, SGRs of large copepodites ( $\mathrm{C} 3$ to female) exhibited a bimodal pattern, being moderate in September/October, slow in November/December and fast in January to March (Fig. 4). This seasonal pattern was less distinct for $\mathrm{C} 5 \mathrm{~s}$, mainly because of the data for December, although this estimate had very low precision. The seasonal pattern of sea surface temperature shows a generally increasing trend from August to March, with little correspondence with the SGR of any stages. However, the seasonal distribution of chl a is bimodal, with high concentrations generally in August to October, lower concentrations in November and December, and larger concentrations in January to March. SGRs of large stages ( $\mathrm{C} 3$ to female) generally followed the chl a concentration, although smaller stages did not.

\section{Event-scale variation}

The comprehensive data set for female Calanus agulhensis enabled investigation of event-scale changes in its SGR in terms of the 4 phases of the upwelling cycle. The classification of the Walker Bay and Cape Agulhas Transects from the January to March period into 4 phases of upwelling is shown in Table 2. SGRs of female $C$. agulhensis from these transects (Fig. 5) were slow at the onset of upwelling $(0.035 \mu \mathrm{gDW}$ $\left.\mu \mathrm{gW}^{-1} \mathrm{~d}^{-1}\right)$, increased during sustained upwelling 
$\left(0.080 \mu \mathrm{gDW} \mu \mathrm{gDW}^{-1} \mathrm{~d}^{-1}\right)$, were fastest during quiescence $\left(0.137 \mu \mathrm{gDW} \mu \mathrm{gDW}^{-1} \mathrm{~d}^{-1}\right)$ and decreased during downwelling $\left(0.049 \mu \mathrm{gDW} \mu \mathrm{gWW}^{-1} \mathrm{~d}^{-1}\right)$.

The cross-shelf pattern of female SGR was dependent upon the phase of the upwelling cycle (Fig. 5) which, in turn, was influenced by prior wind events. At the onset of upwelling, SGR was faster inshore than offshore (Fig. 5a), although there were insufficient data to draw general conclusions. During sustained upwelling, there was a mid-shelf peak in SGR (Fig. 5b). The hydrography of the January 1994 Walker Bay Transect, which was preceded by $2 \mathrm{~d}$ of strong southerly and south-easterly wind, is a typical example of this phase (Fig. 6). Inshore of the upwelling front, SGR was slow in
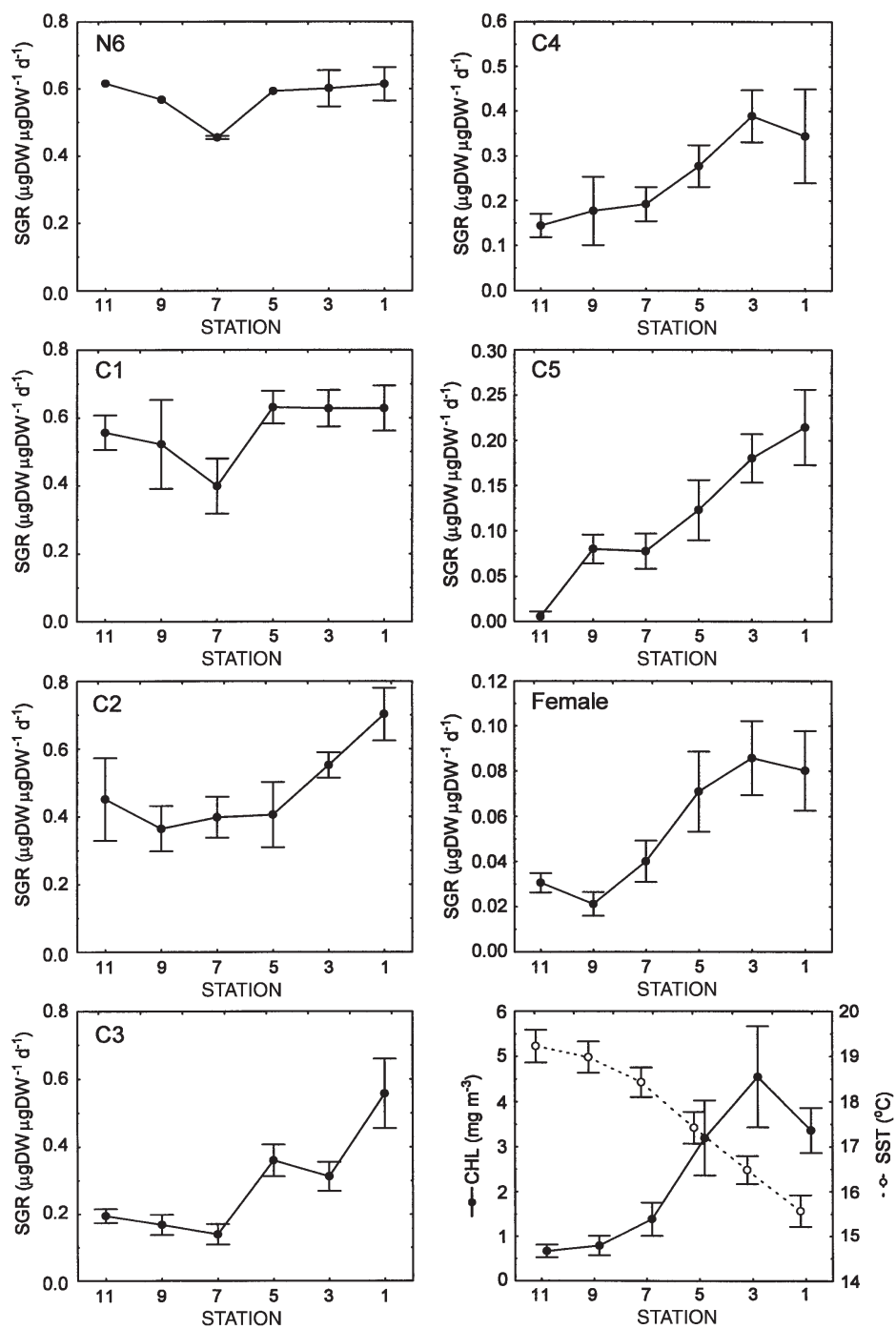

Fig. 3. Calanus agulhensis. Cross-shelf distributions of mean specific growth rate (SGR $\pm \mathrm{SE}$ ) of N6 to female, as well as the overall cross-shelf distribution of sea surface temperature (SST) and surface chl a (bottom right) averaged over the entire sampling period. Stations are numbered from inshore to offshore (see Fig. 1). Note the different $y$-axis scales chlorophyll-poor, newly-upwelled water. Both chl a concentration and female SGR were enhanced in the frontal region around Station 5. Female SGRs slowed beyond the front where phytoplankton biomass was reduced and sub-surface.

Under quiescent conditions, female SGR was elevated over most of the shelf (Fig. 5c). The hydrography of the Walker Bay Transect in March 1994 was typical of this phase (Fig. 7). Weak and variable winds preceded the cruise, allowing the water column to stratify, promoting growth of phytoplankton in the upper mixed layer. The offshore subsurface peak in chl $a_{\text {, }}$ which was apparent during sustained upwelling, was absent. Female SGR was fast over most of the shelf and only decreased in the very warm, chlorophyll-poor water at the furthest station offshore.
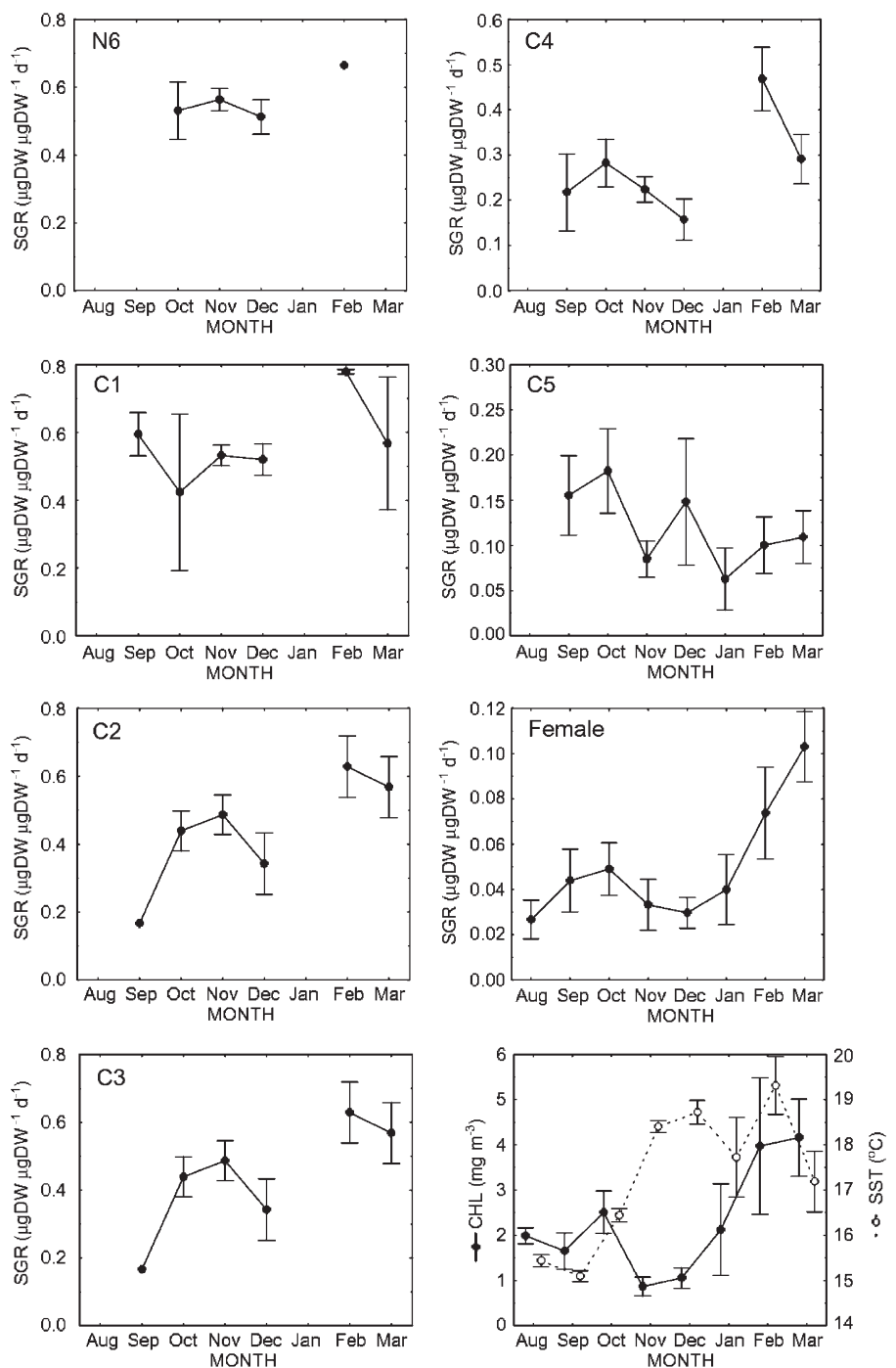

Fig. 4. Calanus agulhensis. Monthly changes in mean specific growth rate (SGR $\pm \mathrm{SE}$ ) of N6 to female, as well as the monthly change in sea surface temperature (SST) and surface chl a averaged over the entire sampling period. Note the different $y$-axis scales 
Table 2. Calanus agulhensis. Specific growth rates $(\mathrm{SGR}$, mean $\pm \mathrm{SE}$ and range) of females for the 4 phases of the upwelling cycle. The number of stations from which each mean was calculated is shown in brackets. Transects that were categorized into each upwelling phase are also shown (after Mitchell-Innes et al. 1999). DW: dry weight; WB: Walker Bay; CA: Cape Agulhas

\begin{tabular}{|c|c|c|c|}
\hline $\begin{array}{l}\text { Upwelling } \\
\text { phase }\end{array}$ & $\begin{array}{l}\text { Mean female SGR } \\
\left(\mathrm{mgDW} \mathrm{mgDW}^{-1} \mathrm{~d}^{-1}\right)\end{array}$ & $\begin{array}{l}\text { Range (mgDW } \\
\left.\mathrm{mgDW}^{-1} \mathrm{~d}^{-1}\right)\end{array}$ & Transect \\
\hline Onset & $0.035 \pm 0.025$ & $0.001-0.083$ & Jan 1994 CA \\
\hline Sustained & $0.080 \pm 0.013(22)$ & $0.013-0.241$ & $\begin{array}{l}\text { Jan } 1994 \text { WB, } \\
\text { Feb } 1994 \mathrm{CA}, \\
\text { Mar } 1994 \mathrm{CA} \text {, } \\
\text { Mar } 1995 \mathrm{WB}, \\
\text { Mar } 1995 \mathrm{CA}\end{array}$ \\
\hline Quiescence & $0.137 \pm 0.022(11)$ & $0.015-0.234$ & $\begin{array}{l}\text { Feb } 1994 \text { WB, } \\
\text { Mar } 1994 \text { WB }\end{array}$ \\
\hline Downwelling & $0.049 \pm 0.014(11)$ & $0.004-0.162$ & $\begin{array}{l}\text { Feb } 1995 \text { WB, } \\
\text { Feb } 1995 \text { CA }\end{array}$ \\
\hline
\end{tabular}

During downwelling, female SGRs were generally slow (Fig. 5d). The Walker Bay Transect in February 1995, after a day of north-westerly winds prior to the cruise (Fig. 8), was representative of this phase. There was doming of the isotherms near the coast, coincident with enhanced chl a concentrations and elevated copepod SGRs. Further offshore, SGRs were depressed as chl a concentrations decreased and became subsurface.

\section{Relationship of specific growth rate to temperature and chl a}

Relationships between SGR of Calanus agulhensis stages and chl a (range: 0.3 to $22.2 \mathrm{mg} \mathrm{m}^{-3}$ ), temperature $\left(9.8\right.$ to $\left.22.5^{\circ} \mathrm{C}\right)$, and the number of individuals incubated (20 to 70 ind.) were summarized by multiple linear regression analysis (Table 3). There was no significant effect on SGRs of the number of individuals that were incubated in a bottle for any stages, implying that food limitation in the bottles did not substantially affect SGRs. SGR was not significantly related to temperature for any stages except $\mathrm{C} 1$, although the negative relationship with temperature for this stage is counterintuitive and is probably a result of the relatively small sample size (Table 1). By contrast, SGR was significantly related to chl a for all stages, except N6. Scatterplots of SGR and chl a suggested saturation of SGR at high chl a levels, so Ivlev curves were fitted for each stage (Table 3 ). These generally provided superior fits to the data, as the proportion of variance explained by the model was greater. There were stronger relationships between SGRs and chl a concentration for larger than for smaller stages, although this did not hold for C5s.

\section{Relationship between sardine spawning and food available to larvae}

The spawning of sardine exhibited 2 major spawning peaks over the 2 spawning seasons: one in September/October and the other in January/February (Fig. 9a). These peaks were coincident with peaks in chl a concentration (Fig. 9a) and the maximum production of eggs by Calanus agulhensis (Fig. 9b). Thus, there were significant positive relationships between the total number of sardine eggs and both chl a concentration (Fig. 9c, r ${ }^{2}=0.71, p<0.001$ ) and the number of $C$. agulhensis eggs available (Fig. 9d, $\mathrm{r}^{2}=0.34, \mathrm{p}<0.05$ ).

\section{DISCUSSION}

This study highlights the importance of hydrography to variation in copepod growth and egg production in a dynamic upwelling system. On the western Agulhas Bank, SGRs of large Calanus agulhensis stages vary seasonally, cross-shelf and at the event-scale, reflecting changes in their food environment in response to physical processes.
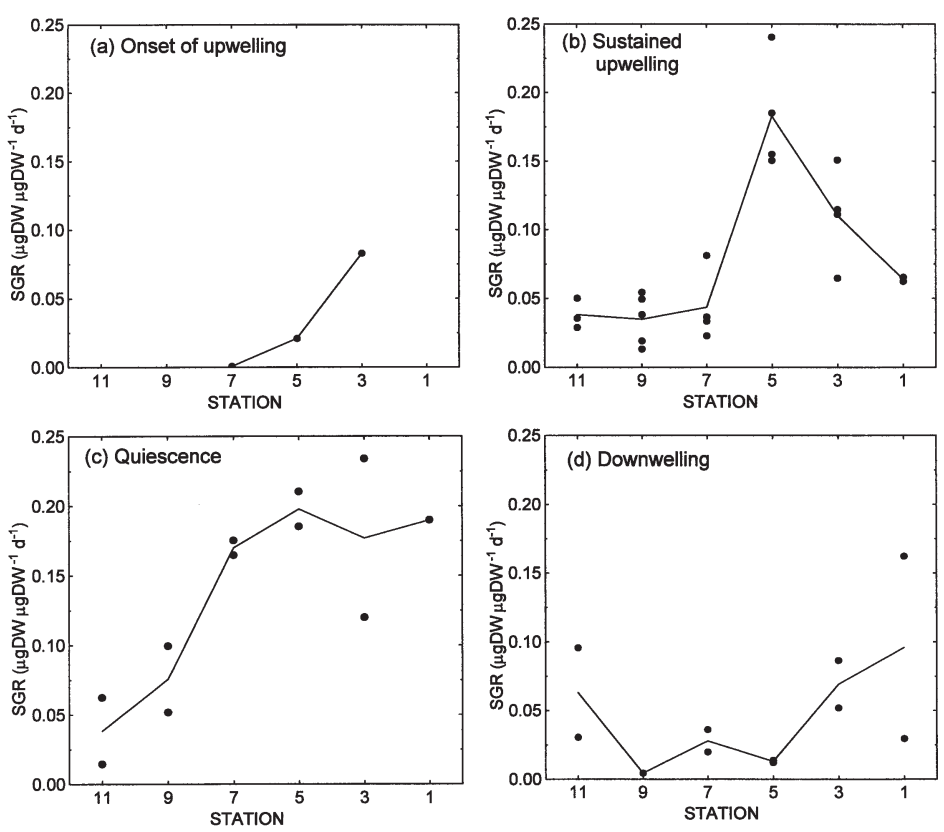

Fig. 5. Calanus agulhensis. Cross-shelf distribution of specific growth rate (SGR) of females from the Cape Agulhas and Walker Bay Transects between January and March, categorized into 4 phases of the upwelling cycle (see Table 2): (a) the onset of upwelling, (b) sustained upwelling, (c) quiescence and (d) downwelling. Transects that were included in each phase of upwelling are shown in Table 2. Dots represent the mean SGR at a station on either the Walker Bay or Cape Agulhas Transects, with the solid line depicting their mean 

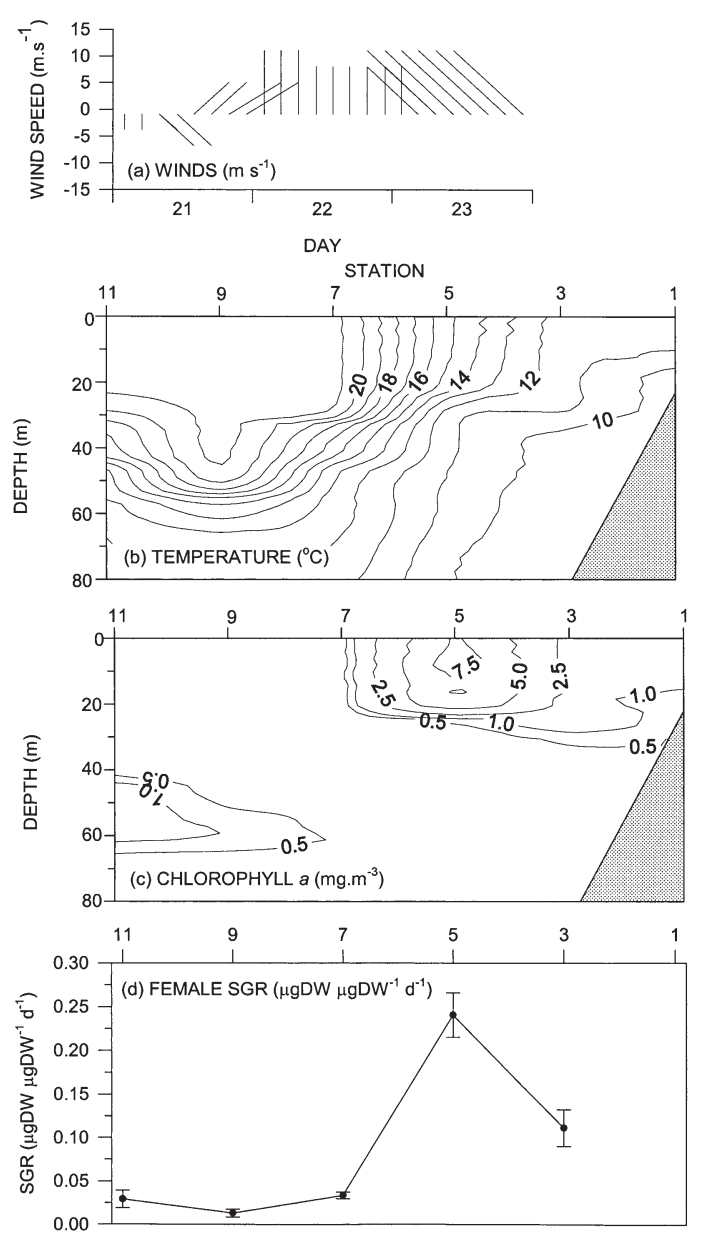

Fig. 6. Calanus agulhensis. Walker Bay Transect in January 1994 during sustained upwelling showing (a) wind strength and direction prior to sampling, vertical sections of (b) temperature and (c) chl $a$, and (d) specific growth rate (SGR $\pm \mathrm{SE}$ ) of females

\section{Cross-shelf and seasonal variation}

SGRs of large copepodites declined across the shelf as chl a concentrations decreased. A reduction in chl a concentration from relatively nutrient-rich waters inshore to oligotrophic oceanic waters further offshore is typical of many regions, including the western Agulhas Bank (Pitcher et al. 1992). Slower growth rates and reduced egg production in response to declining food concentrations offshore have also been observed in female Paracalanus parvus in southern California (Checkley 1980) and in larger copepodites of a tropical copepod community (Webber \& Roff 1995).

SGRs of large copepodites varied seasonally in response to changes in phytoplankton biomass, which in turn was a consequence of seasonal changes in hydrography. In September/October, conditions were favourable for moderate chl a concentrations to develop as the
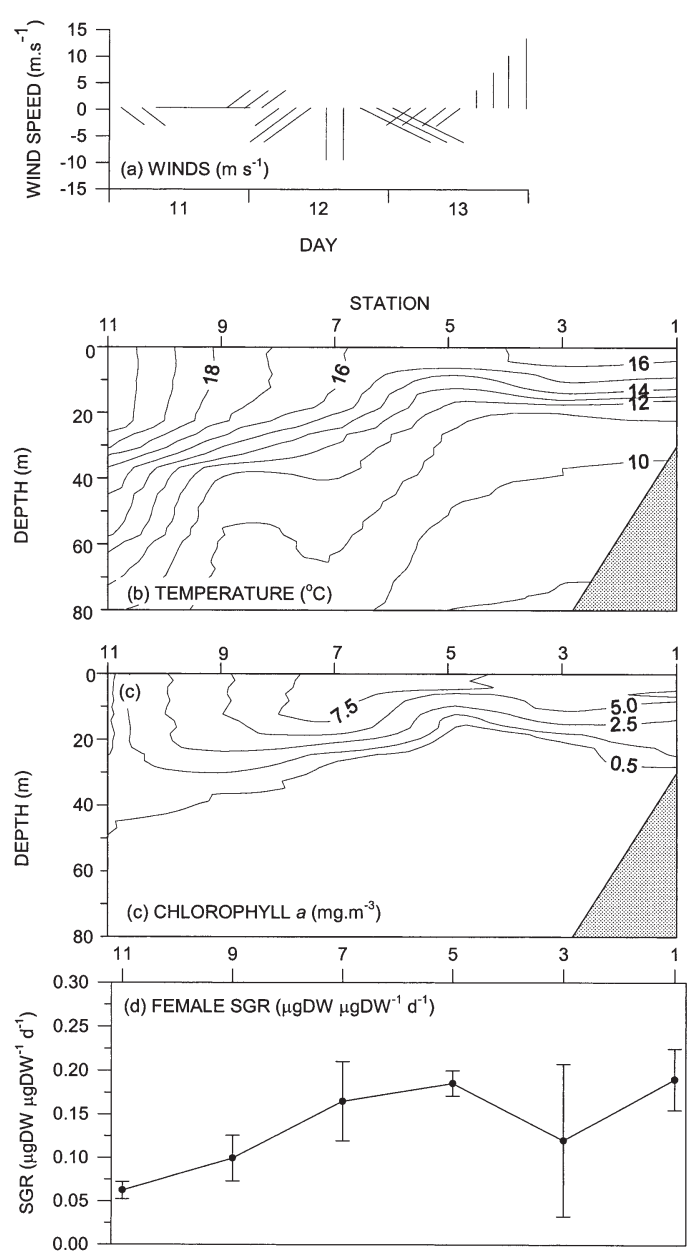

Fig. 7. Calanus agulhensis. Walker Bay Transect in March 1994 during quiescence, (a) to (d) as in Fig. 6

water column stabilized after winter (Mitchell-Innes et al. 1999), following increased insolation and abatement of westerly winds (Boyd et al. 1985). A second period of higher chl a concentration occurred from January to March during periodic surface upwelling. Although upwelling-favourable winds are common from September to March (Shannon 1985, Shillington 1998), it is not until January that the cold bottom water on the western Agulhas Bank is sufficiently shallow to permit surface upwelling of water from below the pycnocline (Mitchell-Innes et al. 1999). This delayed movement of bottom water onto the shelf is a consequence of the broad shelf of the western Bank and the slow transport of bottom water to the region (Chapman \& Largier 1989).

\section{Event-scale variation}

SGRs of Calanus agulhensis females were more variable from January onwards, when hydrographic 
changes at the event scale were greatest. During late summer, rapid cycles of upwelling and relaxation are superimposed on seasonal hydrographic changes (Pitcher et al. 1992). Variation in female SGR across the shelf during different phases of upwelling mirrored changes in chl $a$, which increased from the onset of upwelling to reach a maximum under quiescent conditions and then declined during downwelling (Mitchell-Innes et al. 1999). This is a consequence of phytoplankton bloom development and subsequent successional changes in the assemblage as upwelled water matures (Brown \& Field 1986, Pitcher et al. 1991). At the onset of upwelling, SGR is slow inshore because phytoplankton is virtually absent from newly-upwelled water (Brown \& Field 1986, Pitcher 1990). During sustained upwelling, diatoms dominate maturing upwelled water inshore of the frontal region (Pitcher et al. 1992), and dinoflagellates dominate within the front (Pitcher et al. 1996).
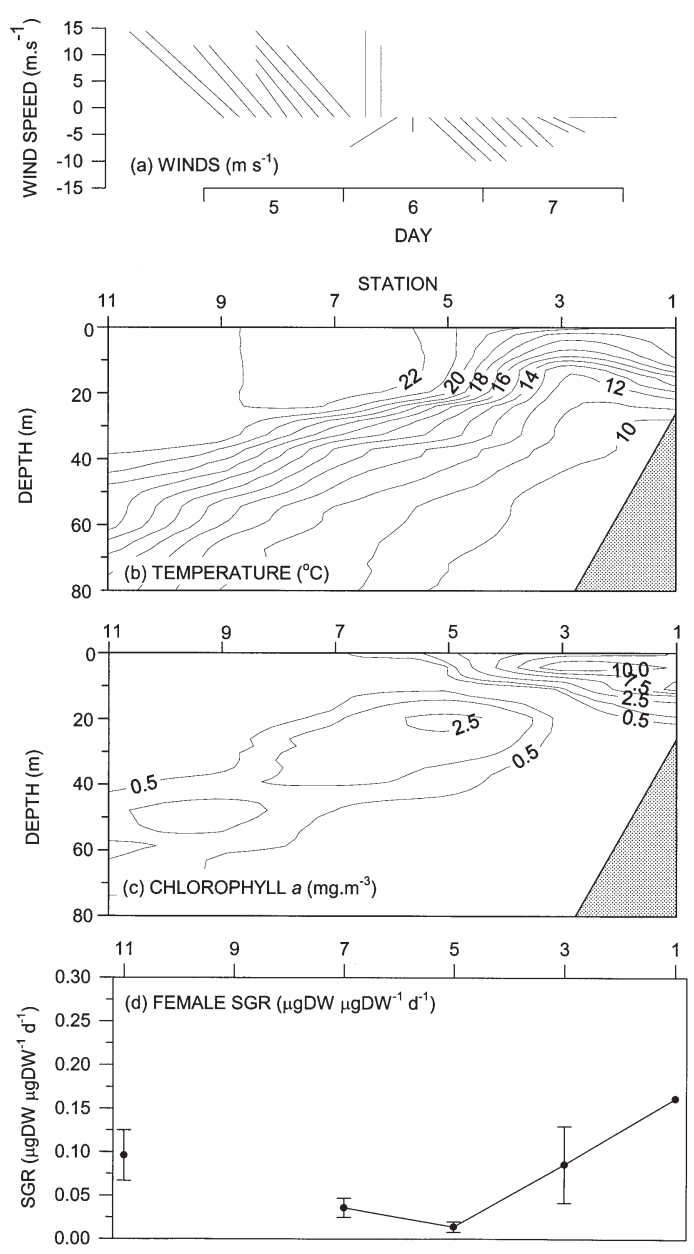

Fig. 8. Calanus agulhensis. Walker Bay Transect in February 1995 during downwelling, (a) to (d) as in Fig. 6
These taxa enhance chl a concentrations, providing a good food environment for copepods (Armstrong et al. 1991, Mitchell-Innes \& Pitcher 1992). During quiescent periods, the broad band of high chl a over most of the shelf that is characteristic of aged-upwelled water (Shannon 1985) supports fast SGRs of large copepods. Maximum egg production of Calanus chilensis, a closely related species from the Humboldt Current upwelling region, was observed during relaxation events (Peterson et al. 1988). Therefore, not only is the duration of upwelling wind events important for enhancing chl a concentrations (and hence elevating female egg production) by injecting nutrients into the upper mixed layer, but also the duration of relaxation (Pitcher et al. 1992).

\section{Relationship of specific growth rate to $\mathrm{chl} \mathrm{a}_{\text {, temper- }}$ ature and size}

The reason for the observed patterns in SGR is its link to food in terms of chl a. Many field studies have found such a relationship (Checkley 1980, Armstrong et al. 1991, Peterson et al. 1991, Durbin et al. 1992, McKinnon \& Thorrold 1993, Plourde \& Runge 1993, Hutchings et al. 1995, Jónasdóttir et al. 1995). It is noteworthy, however, that temperature was not an important factor controlling SGR. This has been found previously for egg production and growth rate of several copepod species throughout the southern Benguela region (Armstrong et al. 1991, Richardson \& Verheye 1998). This is probably because low chl a concentrations are generally associated with warm waters in this system (Mitchell-Innes \& Pitcher 1992, Pitcher et al. 1996), so that copepods cannot grow at temperature-dependent rates (Richardson \& Verheye 1998). Thus, the assertion by Huntley \& Lopez (1992), that copepod growth and egg production in nature are not food limited and are primarily dependent on temperature, is not applicable to an upwelling system such as the southern Benguela. Moreover, control of growth and egg production by food rather than temperature has also been found in many other systems such as freshwater lakes (Ban 1994), tropical seas (McKinnon \& Thorrold 1993, Webber \& Roff 1995) and temperate coastal regions (Peterson \& Bellantoni 1987, Pond et al. 1996).

Another interesting observation is that the SGRs of Calanus agulhensis stages decreased with age, from an asymptotic SGR of $\sim 0.6 \mu \mathrm{gDW} \mu \mathrm{gDW}^{-1} \mathrm{~d}^{-1}$ for young stages to $\sim 0.2 \mu \mathrm{gDW} \mu \mathrm{gDW}^{-1} \mathrm{~d}^{-1}$ for females. This decline has also been observed in the laboratory for a number of species (Paffenhöfer 1976, Vidal 1980). Part of the reason for this is undoubtedly allometric considerations (Peters 1983), where larger organisms 
Table 3. Calanus agulhensis. Results of multiple linear regression analyses and fitting of Ivlev curves. For the regression models, the dependent variable in each case is specific growth rate $\left(\mathrm{SGR}, \mu \mathrm{gDW} \mu \mathrm{gDW}^{-1} \mathrm{~d}^{-1}\right.$ ) and the independent variables are temperature (range: 9.8 to $22.5^{\circ} \mathrm{C}$ ), chl a concentration (range: 0.3 to $22.2 \mathrm{mg} \mathrm{m}^{-3}$ ), and no. of individuals incubated. Standardized partial regression coefficients and the proportion of variance explained $\left(r^{2}\right)$ are given, together with their respective significance level: ns: not significant; ${ }^{*} \mathrm{p}<0.05 ;{ }^{* *} \mathrm{p}<0.01$; ${ }^{* * *} \mathrm{p}<0.001 ;{ }^{* * * *} \mathrm{p}<0.0001$. For the Ivlev curves [SGR $=g_{\mathrm{a}}\left(1-\mathrm{e}^{-k \times c}\right)$ ] relating copepod SGR to chl a concentration $(c)$, values for the asymptotic growth rate $\left(g_{\mathrm{a}}\right)$ and the rate at which SGR approaches this asymptote $(k)$ are given. The number of samples for each stage is given in Table 1

\begin{tabular}{|c|c|c|c|c|c|c|c|}
\hline \multirow[t]{2}{*}{ Stage } & \multicolumn{4}{|c|}{ Multiple linear regression } & \multicolumn{3}{|c|}{ Ivlev curve } \\
\hline & $\begin{array}{l}\text { Tempe- } \\
\text { rature }\end{array}$ & Chl a & $\begin{array}{c}\text { No. ind. } \\
\text { incubated }\end{array}$ & $\mathrm{r}^{2}$ & $g_{\mathrm{a}}$ & $k$ & $\mathrm{r}^{2}$ \\
\hline N6 & ns & ns & ns & - & 0.584 & 6.63 & 0.14 \\
\hline $\mathrm{C} 1$ & -0.315 & 0.421 & ns & $0.34^{* * *}$ & 0.635 & 3.72 & 0.17 \\
\hline $\mathrm{C} 2$ & ns & 0.372 & ns & $0.14^{*}$ & 0.567 & 2.93 & 0.24 \\
\hline $\mathrm{C} 3$ & ns & 0.402 & ns & $0.16^{* *}$ & 0.325 & 2.37 & 0.22 \\
\hline $\mathrm{C} 4$ & ns & 0.524 & ns & $0.27^{* * * *}$ & 0.402 & 1.24 & 0.40 \\
\hline C5 & ns & 0.277 & ns & $0.08^{*}$ & 0.166 & 1.58 & 0.19 \\
\hline Female & ns & 0.645 & - & $0.42^{* * * *}$ & 0.191 & 0.217 & 0.47 \\
\hline
\end{tabular}

SGR vs chl a relationships as body size increased. Thus, SGRs of larger stages $\left(r^{2}>0.4\right)$ were more strongly related to chl a than smaller stages $\left(\mathrm{r}^{2} \sim 0.2\right)$, although this did not hold for Calanus agulhensis C5s, possibly because they often store lipids in preparation for their final moult (Borchers \& Hutchings 1986). This decrease in strength of the relationships with chl a as body size increases implies greater food limitation of larger stages. This has been documented before in the laboratory for C. pacificus and Pseudocalanus spp. (Vidal 1980), and in the field for species in the southern Benguela system (Peterson et al. 1991, Hutchings et al. 1995, Richardson \& Verheye 1999) and in a tropical neritic system (Webber \& Roff 1995).

generally grow more slowly relative to body weight than smaller ones.

It is likely, however, that increased food limitation of larger species is also responsible for the decline in SGR with body size. The evidence supporting this assertion comes from the increased strength of the
The reason for the increased food limitation of larger species is probably because of 3 considerations. First, the optimal cell size to feed upon is related to body size: smaller copepods generally ingest nano- and picoplankton more efficiently than do larger copepods (Berggreen et al. 1988, Webber \& Roff 1995) and larger (a)

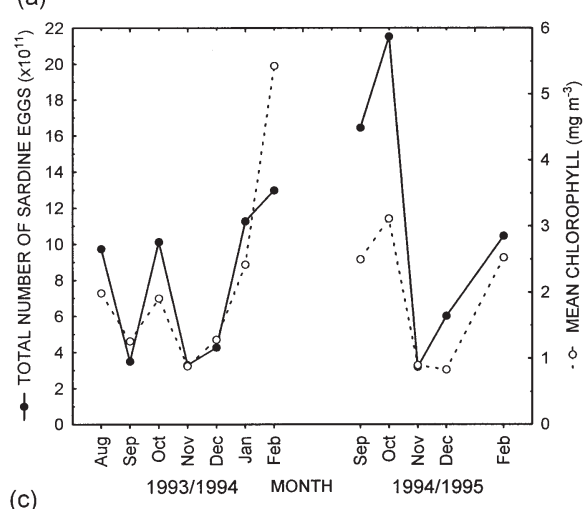

(c)

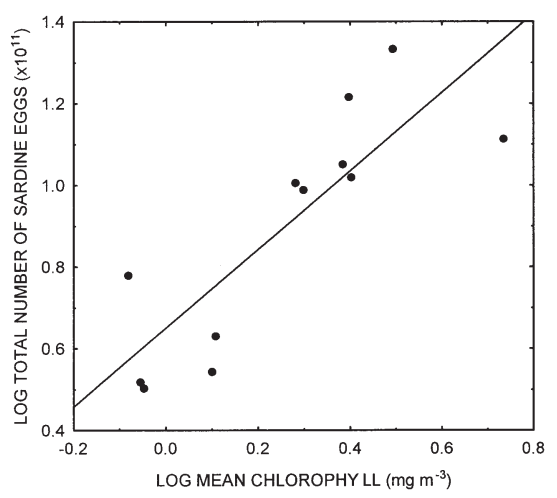

(b)

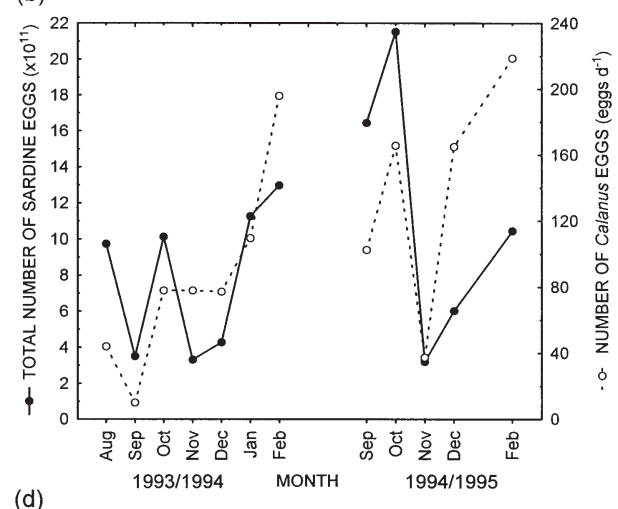

(d)

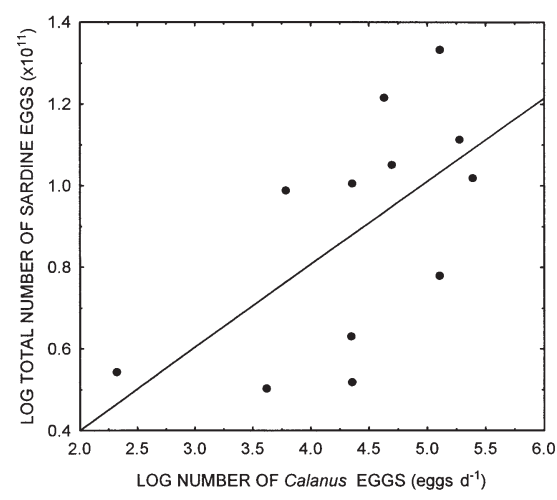

Fig. 9. Sardinops sagax and Calanus agulhensis. Time series for 1993/94 and 1994/95 of (a) the total number of sardine eggs on the western Agulhas Bank and chl a concentration, and (b) the total number of sardine eggs on the western Agulhas Bank and the number of eggs produced by C. agulhensis. The positive correlations between the total number of sardine eggs and (c) chl $a$ concentration $(\log y=-0.00674+$ $0.20347 \log x, \mathrm{r}^{2}=0.71, \mathrm{p}<0.001$ ) and (d) the number of eggs produced by $C$. agulhensis $(\log y=$ $-0.65026+0.961928 \log X_{r} \mathrm{r}^{2}=$ $0.37, \mathrm{p}<0.05)$ are shown 
copepods prefer larger cells (e.g. Frost 1972). Second, smaller cells are ubiquitous in the marine environment, and large cells are found only relatively occasionally. This is even the case in a productive upwelling system such as the Benguela, where over large spatial and temporal scales small cells are at a relatively constant background density and large cells are relatively infrequent (Painting et al. 1993, Richardson \& Verheye 1999). Last, there is insufficient food for larger copepods at the typical concentrations of small cells in an upwelling system such as the Benguela (Mitchell-Innes \& Pitcher 1992), but it is sufficient for the lower metabolic requirements of small copepods. This was evident offshore of the upwelling front, where pico- and nanoplankton such as small flagellates (Armstrong et al. 1987, Pitcher et al. 1992) dominate the reduced phytoplankton biomass, and these small cells do not provide enough food for large copepods.

\section{Implications for the spawning of sardine}

Starvation of fish larvae may be an important factor affecting recruitment (Miller et al. 1988, Pedersen et al. 1990). In temperate regions, fish such as herring, plaice and cod spawn during spring or autumn blooms (Cushing 1967, 1990). At these times, female copepods are spawning rapidly, providing eggs and nauplii that are ingested by fish larvae. In the present study, the strong, positive relationship identified between the spawning of sardine and the food available to firstfeeding larvae (in terms of chl $a$ and the number of eggs produced by Calanus agulhensis) suggest that the South African sardine may also follow this reproductive strategy, timing its spawning to the period of maximum larval food availability. Moreover, the high chl a concentration also provides food for adult sardine that may aid spawning, as sardine obtain a substantial portion of their diet from phytoplankton (Van der Lingen 1994).

There is an additional benefit of sardine spawning where and when they do. In the southern Benguela system, a jet-like current transports pelagic eggs and larvae from spawning grounds on the western Agulhas Bank to recruitment grounds on the west coast of South Africa (Shelton \& Hutchings 1982). The surface front associated with this current has high concentrations of copepod eggs and nauplii (Armstrong et al. 1987), a consequence of the high chl a concentrations, large cell sizes and rapid female egg production in these zones. This would reduce starvation-related mortality of sardine larvae during the transport from the spawning to recruitment grounds.
Acknowledgements. This work was conducted under the auspices of the Benguela Ecology Programme of South Africa. We would like to thank the Chief Directorate: Marine and Coastal Management, Cape Town for their considerable technical, logistical and financial support. Comments by Ms. J. A. Huggett and 3 anonymous reviewers on the manuscript were appreciated. The Benguela Ecology Programme provided funding for A.J.R. and J.L.F.

\section{LITERATURE CITED}

Armstrong DA, Mitchell-Innes BA, Verheye-Dua F, Waldron $\mathrm{H}$, Hutchings L (1987) Physical and biological features across an upwelling front in the southern Benguela. In: Payne AIL, Gulland JA, Brink KH (eds) The Benguela and comparable ecosystems. S Afr J Mar Sci 5:171-190

Armstrong DA, Verheye HM, Kemp AD (1991) Short-term variability during an anchor station study in the southern Benguela upwelling system: fecundity estimates of the dominant copepod, Calanoides carinatus. Prog Oceanogr 28:167-188

Ban S (1994) Effect of temperature and food concentration on post-embryonic development, egg production and adult body size of calanoid copepod Eurytemora affinis. J Plankton Res 16:721-735

Berggreen U, Hansen B, Kiørboe T (1988) Food size spectra, ingestion and growth of the copepod Acartia tonsa during development: implications for determination of copepod production. Mar Biol 99:341-352

Blaxter JHS, Hunter JR (1982) The biology of the clupeoid fishes. Adv Mar Biol 20:1-223

Borchers P, Hutchings L (1986) Starvation tolerance, development time and egg production of Calanoides carinatus in the southern Benguela Current. J Plankton Res 8:855-874

Boyd AJ, Tromp BBS, Horstman D (1985) The hydrology off the South African south-western coast between Cape Point and Danger Point in 1975. S Afr J Mar Sci 3:145-168

Brown PC, Field JG (1986) Factors limiting phytoplankton production in a nearshore upwelling area. J Plankton Res 8:55-68

Chapman P, Largier JL (1980) On the origin of Agulhas Bank bottom water. S Afr J Sci 85:515-519

Checkley DM Jr (1980) Food limitation of egg production by a marine, planktonic copepod in the seas off southern California. Limnol Oceanogr 25:991-998

Cushing DH (1967) The grouping of herring populations. J Mar Biol Assoc UK 47:193-208

Cushing DH (1990) Plankton production and year-class strength in fish populations: an update of the match/mismatch hypothesis. Adv Mar Biol 26:249-293

Davis CS (1987) Components of the zooplankton production cycle in the temperate ocean. J Mar Res 45:947-983

Durbin EG, Durbin AG, Campbell RG (1992) Body size and egg production in the marine copepod Acartia hudsonica during a winter-spring diatom bloom in Narragansett Bay. Limnol Oceanogr 37:342-360

Frost BW (1972) Effects of size and concentration of food particles on the feeding behavior of the marine planktonic copepod Calanus pacificus. Limnol Oceanogr 17:805-815

Gifford DJ (1993) Planktonic protozoa in copepod diet: examples from the North Atlantic and the North Pacific. ICES Council Meeting Papers, Copenhagen

Harris RP (1996) Feeding ecology of Calanus. Ophelia 44:85-109

Huggett JA, Richardson AJ (2000) A review of the biology of Calanus agulhensis off South Africa. ICES J Mar Sci 57: 1834-1849 
Huggett JA, Boyd AJ, Hutchings L, Kemp AD (1998) Weekly variability of clupeoid eggs and larvae in the Benguela jet current: implications for recruitment. In: Pillar SC, Moloney CL, Payne AIL, Shillington FA (eds) Benguela dynamics. Impacts of variability on shelf-sea environments and their living resources. S Afr J Mar Sci 19: $197-210$

Huntley ME, Lopez MDG (1992) Temperature-dependent production of marine copepods: a global synthesis. Am Nat 140:201-242

Hutchings L, Verheye HM, Mitchell-Innes BA, Peterson WT, Huggett JA, Painting SJ (1995) Copepod production in the southern Benguela system. ICES J Mar Sci 52:439-455

Jónasdóttir SH, Fields D, Pantoja S (1995) Copepod egg production in Long Island Sound, USA, as a function of the chemical composition of seston. Mar Ecol Prog Ser 119: 87-96

Jury MR (1988) A climatological mechanism for wind-driven upwelling near Walker Bay and Danger Point, South Africa. S Afr J Mar Sci 6:175-181

Kleppel GS (1993) On the diets of calanoid copepods. Mar Ecol Prog Ser 99:183-195

Laabir M, Poulet SA, Ianora A (1995) Measuring production and viability of eggs in Calanus helgolandicus. J Plankton Res 17:1125-1142

Largier JL, Chapman P, Peterson WT, Swart VP (1992) The western Agulhas Bank: circulation, stratification and ecology. In: Payne AIL, Brink KH, Mann KH, Hilborn R (eds) Benguela trophic functioning. S Afr J Mar Sci 12:319-339

Mauchline J (1998) The biology of calanoid copepods. In: Blaxter JHS, Southward AJ, Tyler PA (eds). Advances in marine biology, Vol 33. Academic Press, San Diego

McKinnon AD, Ayukai T (1996) Copepod egg production and food resources in Exmouth Gulf, Western Australia. Mar Freshw Res 47:595-603

McKinnon AD, Thorrold SR (1993) Zooplankton community structure and copepod egg production in coastal waters of the central Great Barrier Reef lagoon. J Plankton Res 15: $1387-1411$

McLaren IA, Corkett CJ (1981) Temperature-dependent growth and production by a marine copepod. Can J Fish Aquat Sci 38:77-83

McLaren IA, Tremblay MJ, Corkett CJ, Roff JC (1989) Copepod production on the Scotian Shelf based on life-history analyses and laboratory rearings. Can J Fish Aquat Sci 46: 560-583

Middlebrook K, Roff JC (1986) Comparison of methods for estimating annual productivity of the copepods Acartia hudsonica and Eurytemora herdmani in Passamaquoddy Bay, New Brunswick. Can J Fish Aquat Sci 43:656-664

Miller TJ, Crowder LB, Rice JA, Marschall EA (1988) Larval size and recruitment mechanisms in fishes: toward a conceptual framework. Can J Fish Aquat Sci 45:1657-1670

Mitchell-Innes BA, Pitcher GC (1992) Hydrographic parameters as indicators of the suitability of phytoplankton populations as food for herbivorous copepods. In: Payne AIL, Brink KH, Mann KH, Hilborn R (eds) Benguela trophic functioning. S Afr J Mar Sci 12:355-365

Mitchell-Innes BA, Richardson AJ, Painting SJ (1999) Seasonal and event-scale changes in phytoplankton dynamics on the western Agulhas Bank. S Afr J Mar Sci 21:217-233

Mostert SA (1988) Notes on improvements and modifications to the automatic methods for determining dissolved micronutrients in seawater. S Afr J Mar Sci 7:295-298

Paffenhöfer GA (1976) Feeding, growth, and food conversion of the marine planktonic copepod Calanus helgolandicus. Limnol Oceanogr 21:39-50
Painting SJ (1993) Sardine and anchovy recruitment prediction - South Africa. US Globec News 5:1-2

Painting SJ, Lucas MI, Peterson WT, Brown PC, Hutchings L, Mitchell-Innes BA (1993) Dynamics of bacterioplankton, phytoplankton and mesozooplankton communities during the development of an upwelling plume in the southern Benguela. Mar Ecol Prog Ser 100:35-53

Parsons TR, Maita Y, Lalli CM (1984) A manual of chemical and biological methods for seawater analysis. Pergamon Press, New York

Pedersen BH, Ugelstad I, Hjelmeland K (1990) Effects of a transitory, low food supply in the early life of larval herring (Clupea harengus) on mortality, growth and digestive capacity. Mar Biol 107:61-66

Peters RH (1983) The ecological implications of body size. Cambridge University Press, Cambridge

Peterson WT, Bellantoni DC (1987) Relationships between water-column stratification, phytoplankton cell size and copepod fecundity in Long Island Sound and off central Chile. In: Payne AIL, Gulland JA, Brink KH (eds) The Benguela and comparable ecosystems. S Afr J Mar Sci 5: 411-421

Peterson WT, Arcos DF, McManus GB, Dam H, Bellantoni D, Johnson T, Tiselius $P$ (1988) The nearshore zone during coastal upwelling: daily variability and coupling between primary and secondary production off central Chile. Prog Oceanogr 20:1-40

Peterson WT, Tiselius P, Kiørboe T (1991) Copepod egg production, moulting and growth rates, and secondary production, in the Skagerrak in August 1988. J Plankton Res 13:131-154

Pitcher GC (1990) Phytoplankton seed populations of the Cape Peninsula upwelling plume, with particular reference to resting spores of Chaetoceros (Bacillariophyceae) and their role in seeding upwelling waters. Estuar Coast Shelf Sci 31:283-301

Pitcher GC, Walker DR, Mitchell-Innes BA, Moloney CL (1991) Short-term variability during an anchor station study in the southern Benguela upwelling system: phytoplankton dynamics. Prog Oceanogr 28:39-64

Pitcher GC, Brown PC, Mitchell-Innes BA (1992) Spatiotemporal variability of phytoplankton in the southern Benguela upwelling system. In: Payne AIL, Brink KH, Mann $\mathrm{KH}$, Hilborn R (eds) Benguela trophic functioning. S Afr J Mar Sci 12:439-456

Pitcher GC, Richardson AJ, Korrûbel JL (1996) The use of sea temperature in characterizing the mesoscale heterogeneity of phytoplankton in an embayment of the southern Benguela upwelling system. J Plankton Res 18:643-657

Plourde S, Runge JA (1993) Reproduction of the planktonic copepod Calanus finmarchicus in the lower St. Lawrence Estuary: relation to the cycle of phytoplankton production and evidence for a Calanus pump. Mar Ecol Prog Ser 102: $217-227$

Pond D, Harris R, Head R, Harbour D (1996) Environmental and nutritional factors determining seasonal variability in the fecundity and egg viability of Calanus helgolandicus in coastal waters off Plymouth, UK. Mar Ecol Prog Ser 143: $45-63$

Richardson AJ, Verheye HM (1998) The relative importance of food and temperature to copepod egg production and somatic growth in the southern Benguela upwelling system. J Plankton Res 20:2379-2399

Richardson AJ, Verheye HM (1999) Growth rates of copepods in the southern Benguela upwelling system: the interplay between body size and food. Limnol Oceanogr 44: 382-392 
Richardson AJ, Mitchell-Innes BA, Fowler JL, Bloomer SF, Field JG, Verheye HM, Hutchings L, Painting SJ (1998) The effect of sea temperature and food availability on the spawning success of the Cape anchovy Engraulis capensis in the southern Benguela. In: Pillar SC, Moloney CL, Payne AIL, Shillington FA (eds) Benguela dynamics. Impacts of variability on shelf-sea environments and their living resources. S Afr J Mar Sci 19:275-290

Shannon LV (1985) The Benguela ecosystem, Part I. Evolution of the Benguela, physical features and processes. Oceanogr Mar Biol Annu Rev 23:105-182

Shelton PA (1986) Fish spawning strategies in the variable southern Benguela current region. PhD thesis, University of Cape Town

Shelton PA, Hutchings L (1982) Transport of anchovy, Engraulis capensis Gilchrist, eggs and early larvae by a frontal jet current. J Cons Int Explor Mer 40:185-198

Shillington FA (1998) The Benguela upwelling system off southwestern Africa. In: Robinson AR, Brink KH (eds) The sea, Vol. 11. John Wiley \& Sons, New York, p 583-604

Turner JT (1984) The feeding ecology of some zooplankters

Editorial responsibility: Michael Landry (Contributing Editor), Honolulu, Hawaii, USA that are important prey items of larval fish. NOAA Tech Rep NMFS 7:1-28

Van der Lingen CD (1994) Effect of particle size and concentration on the feeding behaviour of adult pilchard Sardinops sagax. Mar Ecol Prog Ser 109:1-13

Verheye HM, Hutchings L, Huggett JA, Carter RA, Peterson WT, Painting SJ (1994) Community structure, distribution and trophic ecology of zooplankton on the Agulhas Bank with special reference to copepods. S Afr J Sci 90:154-164

Vidal J (1980) Physioecology of zooplankton. I. Effects of phytoplankton concentration, temperature, and body size on the growth rate of Calanus pacificus and Pseudocalanus sp. Mar Biol 56:111-134

Walker DR, Peterson WT (1991) Relationships between hydrography, phytoplankton production, biomass, cell size and species composition, and copepod production in the southern Benguela upwelling system in April 1988. S Afr J Mar Sci 11:289-305

Webber MK, Roff JC (1995) Annual biomass and production of the oceanic copepod community off Discovery Bay, Jamaica. Mar Biol 123:481-495

Submitted: August 30, 2001; Accepted: January 27, 2003

Proofs received from author(s): May 5, 2003 